\title{
Phytochemical analysis and antimicrobial activity of the extract of leaves of fleabane (Conyza sumatrensis)
}

\author{
Jack, I.R; OKOROSAYE-ORUBITE, K. \\ Department of chemistry, Rivers State University of Science and Technology. Port Harcourt.
}

\begin{abstract}
Phytochemical analysis of the extracts from the leaves of the plant fleabane (Conyza sumatrensis) revealed the presence of some substances such as tannins, flavonoids, saponins, steroids and glycosides. The presence of these substances is an indicator of the pharmacological property as well as the nutritive value of the plant leaves. Antimicrobial tests showed that the leaves extract is not sensitive towards the bacteria Pseudomonas aureginosa, staphylococcus aureus, Bacillus spp and Escherichia coli, but inhibited the growth of the fungus Aspergilus niger. @ JASEM
\end{abstract}

With the phenomenal growth in world population and the attendant depletion in food and drugs, mankind has to grapple with these problems by looking for alternative sources for these essentials of life. Consequently, the search for and use of drugs and dietary supplements derived from plants have accelerated in recent years.

Though plants play significant roles in metabolic activities such as photosynthesis and respiration, the choice for food and drugs is predicated on the presence of photochemicals (Nsi and Dyegh, 2004). These are chemical substances present in plants and include alkaloids saponins, glycosides, tannins, flavonoids and steroids. The importance of these phytochemicals cannot be overemphasized as some have been used for the treatment and control of diseases (Iwu et al; 1999, Ayandele and Adebiyi, 2007) while others are known to inhibit the growth of microorganisms (Okerelu and Ani, 2001; Alinor, 2006, Farnsworth, 1996 and Ogbeche et al; 1997).

Conyza sumatrensis commonly called broadleaf fleabane is a dicotyledonous herb of the asteraceae family occurring widely in Nigeria especially in the Niger Delta region and also in central Kenya. It is an erect, hairy, annual herb upto $120 \mathrm{~cm}$ high with sessile and deeply serrated leaves. The most prominent uses of conyza summatresis in Nigeria include treatment of stomach disorder and facial pimples. It also serves as a good source of food for the fowls. It is the success recorded in the treatment of facial pimples with extract from the leaves of conyza sumatrensis that has prompted the investigation into the phytochemical constituents as well as the antimicrobial activities of the plant. By this approach, we hope to develop an effective but cheap and readily available antifungal product for use.

\section{MATERIALS AND METHODS}

The plant was collected from Choba, a village in Rivers State of Nigeria, thoroughly washed with water and $25 \mathrm{~g}$ of the fresh leaves were steam distilled. The steam volatile fraction was obtained by extraction with $\mathrm{n}$-hexane $(50 \mathrm{mlx} 3)$, washed with water $(100 \mathrm{mlx} 2)$ and dried over anhydrous sodium sulphate. Evaporation of the n-hexane solvent gave $1.38 \mathrm{~g}$ of crude extract. The ethanol extract was obtained by soaking the leaves in a round bottom flask containing $200 \mathrm{ml}$ of ethanol for forty-eight hours with shaking occasionally.

The ethanol extract was filtered through $110 \mathrm{~mm}$ Whatman filter paper and evaporated to give $4.28 \mathrm{~g}$ crude extract. Thin layer chromatography (TLC) were run on silica gel 254 and eluted with 4 toluene: 1 ethylacetate.

All reagents and solvents used were purified before use.

\section{Photochemical analysis}

The phytochemical analysis of the plant was carried out by the standard methods provided by Odebiyi and Ramstard, 1978 and Waterman (1993).

\section{Test for tannins}

(a) $1 \mathrm{~cm}^{3}$ of freshly prepared $10 \% \mathrm{KOH}$ was added to $1 \mathrm{~cm}^{3}$ of each of the extracts and observed for dirty white precipitate.

(b) 2 drops of $5 \% \mathrm{Fe} \mathrm{Cl}_{3}$ was added to $1 \mathrm{~cm}^{3}$ of the extracts and observed for green precipitate.

Test for saponins (frothing test).

$2 \mathrm{~cm}^{3}$ of each extract in a test tube was vigorously shaken for two minutes and observed for persistent foaming.

Test for Flavonoids

To $3 \mathrm{~cm}^{3}$ of each extract was added $1 \mathrm{~cm}^{3} \mathrm{NaOH}$ and observed for yellow colouration.

\section{Salkwoski's for test steroids}

5 drops of concentrated $\mathrm{H}_{2} \mathrm{SO}_{4}$ was added to $1 \mathrm{~cm}^{3}$ of each extract and observed for red colouration.

\section{Fehling's test for glycosides.}

$10 \mathrm{~cm}^{3}$ of $50 \% \mathrm{H}_{2} \mathrm{SO}_{4}$ was added to $1 \mathrm{~cm}^{3}$ of the extract in a test tube. The mixture was heated in a 
boiling water-bath for 15 minutes. $10 \mathrm{~cm}^{3}$ of fehling's solution was added and the mixture was boiled and observed for brick red precipitate.

\section{Test for alkaloids}

$1 \mathrm{~cm}^{3}$ of $\mathrm{HCl}$ was added to $3 \mathrm{~cm}^{3}$ of each extract in a test tube. The mixture was heated for 20 minutes, cooled and filtered. 2 drops of Wagner's reagent was added to $1 \mathrm{~cm}^{3}$ of the filtrate and observed for reddish brown precipitate.

\section{Antimicrobial screening}

The antimicrobial activities of the crude extract were screened (Moore and Winston, 1996) against four bacteria namely Pseudomonas aeruginosa, staphylococcus aureus, bacillus spp and Escherichia coli and two fungi; Aspergilus niger and Candida albicans. The nutrient agar medium was prepared and sterilized in an autoclave at $121^{\circ} \mathrm{C}$ and $1.1 \mathrm{~N}$ pressure for 15 minutes and allowed to cool and solidity in Petri dishes to a depth of $4 \mathrm{~mm}$ (Ekpendu et al 2001). Pure cultures of the microorganisms were separately used to inoculate the Petri dishes and incubated at $37^{0} \mathrm{C}$ for 24 hours for bacteria and at room temperature for 72 hours for fungi.

\section{RESULTS AND DISCUSSION}

The photochemical analysis of conyza sumatrensis revealed the presence of tannins, flavonoids, saponins, steroids and glycosides in both the nhexane and ethanol extracts (Table 1).

Table 1: Phytochemical Analysis of the Extracts of Fleabane

\begin{tabular}{llll}
\hline Active principle & Test & n-hexane extract & ethanol extract \\
\hline Tannins & $\mathrm{FeCl}_{3}$ & + & + \\
Saponins & Frothing test & + & + \\
Flavonoids & NaOH & + & + \\
Steroids & Salkwoski & + & + \\
Glycosides & Fehling's test & + & + \\
\hline Alkaloids & Wagner's test & - & - \\
\hline \multicolumn{1}{c}{ Key $=$} & + & is present &
\end{tabular}

Table 2A: Percentage yield of n-hexane and ethanol extracts

\begin{tabular}{lllcccc}
\hline Extract & Wt of extract $(\mathrm{g})$ & $\begin{array}{c}\text { Mean }(\mathrm{g}) \\
\mathrm{X}\end{array}$ & $\begin{array}{l}\% \\
\text { Yield }\end{array}$ & $\begin{array}{l}\text { Degree } \\
\text { of } \\
\text { Freedom }\end{array}$ & $\begin{array}{l}\text { Standard } \\
\text { deviation }\end{array}$ & $\begin{array}{l}\text { Confidence interval of } \\
\text { mean test at } 95 \%\end{array}$ \\
\hline n-hexane & $0.80-0.82$ & 0.81 & 3.2 & 3 & 0.01 & $0.81 \pm 0.021$ \\
\hline Ethanol & $4.0-4.3$ & 4.30 & 17.2 & 3 & 0.02 & $4.3 \pm 0.032$ \\
\hline
\end{tabular}

Table 2B Variable ratio $\left(\mathrm{F}_{\text {test }}\right)$ for n-hexane and ethanol extract

\begin{tabular}{llllll}
\hline Standard deviation & $\begin{array}{l}\text { Standard } \\
\text { deviation }\end{array}$ & $\begin{array}{l}\text { Degree of } \\
\text { Freedom }\end{array}$ & F (Calculated) & $\begin{array}{l}\mathrm{F} \text { values } \\
\text { at 95\% }\end{array}$ & Observation \\
\hline n-hexane & Ethanol & & 2.1 & 3.18 & No significant difference \\
\hline
\end{tabular}

Table 3: TLC results for $n$-hexane and ethanol extracts

\begin{tabular}{|c|c|c|c|c|c|c|c|c|}
\hline Extract & $\begin{array}{l}\text { Solvent } \\
\text { System }\end{array}$ & $\begin{array}{l}\text { No. of } \\
\text { Components }\end{array}$ & $\begin{array}{l}R_{\mathrm{f}} \text { value } \\
\text { ranges }(\mathrm{cm})\end{array}$ & $\begin{array}{l}\text { Mean } \bar{x} R_{f} \\
\text { value }(\mathbf{c m})\end{array}$ & $\begin{array}{l}\text { Standard } \\
\text { deviation (cm) }\end{array}$ & $\begin{array}{l}\text { Degree of } \\
\text { freedom }\end{array}$ & $\begin{array}{l}\text { Confidence interval } \\
\text { of mean test at } 95 \%\end{array}$ & Intensity \\
\hline n-hexane & $\begin{array}{l}4 \text {-Toluence } \\
1 \text { Ethl-acetate }\end{array}$ & 1 & $0.80-0.81$ & 0.81 & 0.01 & 3 & $0.081 \pm 0.016$ & $\mathrm{~F}$ \\
\hline Ethanol & -do- & 3 & $\begin{array}{l}0.64-0.66 \\
0.49-0.51 \\
0.36-0 . .39\end{array}$ & $\begin{array}{l}0.65 \\
0.50 \\
0.38\end{array}$ & $\begin{array}{l}0.066 \\
0.006 \\
0.013\end{array}$ & $\begin{array}{l}3 \\
3 \\
3\end{array}$ & $\begin{array}{l}0.65 \pm 0.1 \\
0.51 \pm 0.01 \\
0.38 \pm 0.02\end{array}$ & $\begin{array}{l}\text { V..I } \\
\text { M.I } \\
\text { V.I }\end{array}$ \\
\hline
\end{tabular}

Key $\mathrm{F}=$ Faint

V.I $=$ Very intense

M.I $=$ Moderately intense

TABLE 4: Antimicrobial Analysis

\begin{tabular}{|c|c|c|c|}
\hline \multirow[t]{2}{*}{ S/no } & \multirow[t]{2}{*}{ Micro organism } & \multicolumn{2}{|c|}{ Concentration } \\
\hline & & $20 \mathrm{mg} / \mathrm{ml}$ & $50 \mathrm{mg} / \mathrm{ml}$ \\
\hline 1. & Psendomonas aeruginosa & - & - \\
\hline 2. & Staphylococcus aureus & - & - \\
\hline 3. & Bacillus spp & - & - \\
\hline 4. & Escherichia coli & - & - \\
\hline 5. & Candida Albicans & - & - \\
\hline \multirow[t]{2}{*}{6.} & Aspergilus niger & ++ & ++ \\
\hline & $\begin{array}{c}- \\
++\end{array}$ & $\begin{array}{l}\text { Resist } \\
\text { Sensit }\end{array}$ & \\
\hline
\end{tabular}

* Corresponding author: Jack, I.R. 
The presence of these phytochemicals is an indicator that the plant can be a potential source of precursors in the development of synthetic drugs. Alkaloids were however absent and this suggests that the plant may not be toxic. This evidence is corroborated by the fact that the plant provides a ready source of food for the domestic fowls.

Relatively, low yields pf extracts were obtained for both solvents, i.e. $3.2 \%$ for n-hexane and $17.3 \%$ for ethanol (Tables 2A and 2B). Since steam distillation of the plant and subsequent extraction with n-hexane gave much lower yields, it may be presumed that the components are not very steam volatile.

Statistical analysis of tables 2 and 3 however gives an indication of the precision of the measurements obtained for both solvents. Table $2 \mathrm{~B}$ confirms that there is no significant difference in the precision of weight of extract obtained from the two solvents.

The faint intensity of the spot having $R_{f}$ values of 0.81 on $\mathrm{T} \mathrm{L} \mathrm{C} \mathrm{after} \mathrm{staining} \mathrm{with} \mathrm{iodine} \mathrm{vapour}$ suggests that the component is either saturated or aromatic (Table 3 ).

The artificial culture medium used for the antimicrobial test showed that the ethanol extract from conyza sumatrensis has no antimicrobial activity against Pseudomonas aureqinosa, Staphylococcus aureus, Bacillus SPP and Escherichia coli: When tested on two fungi namely Candida albicans and Aspergilus niger however, the culture medium showed sensitivity towards the latter by inhibiting its growth at moderate and high concentrations of $20 \mathrm{mg} / \mathrm{ml}$ and $50 \mathrm{mg} / \mathrm{ml}$ respectively (Table 4).

This inhibition gives credence to the fact that conyza sumatrensis is an antifungal plant and hence can be used in the treatment of ailment due to this fungus.

\section{REFERENCES}

Alinor, L. J., (2006). Preliminary photochemical and antimicrobial activity of Garcinia cola. J. Chem Soc. Nig. 32 (2) 41-47
Ayandele, A. and Adebiyi, A.O. (2007). Antimimcrobial screening of extracts of Olax Subscorpiodes African J. Biotech. Vol. 6 No. 7 $868-870$

Ekpendu, J.O.E., Ekundayo, O and Laokso, L. (2001). Preparation of nutrient agar medium. J. Chem. Soc. Nig. Vol. 26 No. 2194.

Farnsworth, N.R. (1994). Biological and photochemical screening of plants. J. Pharm. Sciences 55, 225-276

Iwu, M.W; Duncan, A.R. and Okunji. C. O. (1999). New antimicrobials of plant origin. Janick $\mathrm{J}$. Educ. 457-462

Moore, W. and Winston, A. (1996). Laboratory manual for organic microscope approach Pub. McGraw Hill Co. Inc USA

Nsi,E.W. and Dyegh, A.H. (2004). Preliminary photochemical screening and antimicrobial activity of terminalia Avicennioides, Int. J. Sc \& Tech. No. 3 Vol. 2 42-44

Odebiyi, E.O and Ramstard, A. H. (1978). Investigation photochemical screening and antimicrobial screening of extracts of Tetracarpidium conophorum J. Chem Soc. Nig. 261

Ogbeche, A. K; Ajayi, G.O. and Onyenta, P. (1997). Antimicrobial activities of the leaf extracts of Amgeratum conyzoids; Nig. Q.J. Hospital Med. Vol. 7 397-399.

Waterman, P.G. (1993). Methods in plant Biochemistry, vol. 8 Acad. Press 2.

* Corresponding author: Jack, I.R. 